\title{
Information, knowledge and collaboration management in the internationalisation of SMEs: a systematic literature review
}

Eric Costa (eric.m.costa@inesctec.pt), António Lucas Soares (als@fe.up.pt), Jorge Pinho de Sousa (jsousa@inescporto.pt)

INESC TEC - INESC Technology and Science and FEUP - Faculty of Engineering, University of Porto, Campus da FEUP, Rua Dr. Roberto Frias 378, 4200-465 Porto, Portugal

\begin{abstract}
Information and knowledge can be seen as key resources for improving the internationalisation processes of small and medium-sized enterprises (SMEs). Collaboration has also been considered as an important facilitator of these processes, particularly by nurturing information and knowledge sharing. However, the current literature is unclear about the way SMEs can access information and assimilate knowledge in a collaborative network context, to support decision-making. This paper systematically reviews the literature, examining the role of information, knowledge and collaboration in internationalisation decisions of SMEs. To this end, 38 relevant journal articles were analysed, with the identification of some important issues, as well as gaps in the existing empirical knowledge. This analysis provided valuable input for the development of research suggestions and directions for future work in this area.
\end{abstract}

Keywords: Systematic literature review, internationalisation, information management, knowledge management, collaboration.

\section{Introduction}

There is growing evidence that internationalisation has become a key requirement for SMEs to gain competitive advantage which results in an increasing effort in managing the companies' internationalisation processes (Dutot, Bergeron, \& Raymond, 2014; Schweizer, 2012). The effectiveness of those processes is directly related with the way companies manage internationalisation related information (Benito, Solberg, \& Welch, 1993; Child \& Hsieh, 2014; Knight \& Liesch, 2002), establish collaborative networks (Ciravegna, Lopez, \& Kundu, 2014; Musteen, Francis, \& Datta, 2010; Spence, Manning, \& Crick, 2008) and learn and use internationalisation related knowledge (Basly, 2007; Fletcher \& Harris, 2012; Rodriguez, Barcos, \& Álvarez, 2010).

Information of greater explicitness and broader scope allows for a more rational decision-making (Child \& Hsieh, 2014), but the decision-makers capability for identifying, seeking and processing information is also essential for more effective internationalisation decisions (Hsu, Chen, \& Cheng, 2013). Information and knowledge are recognised as crucial to manage international complexity and ambiguity (Hsu, Chen, \& Cheng, 2013), to reduce risks and uncertainty (Nguyen, Barrett, \& Fletcher, 2006), and to stimulate awareness of foreign market opportunities (Zhou, Wu, \& Luo, 2007). From another perspective, it has been found that collaboration, in particular when it unfolds in the context of networks, is an important facilitator in the internationalisation of SMEs (Hutchinson, Alexander, Quinn, \& Doherty, 2007). In making part of collaborative networks, SMEs' internationalisation processes benefit in ways such as: (i) providing decision-makers with important channels of information and knowledge (Musteen et al., 2010); (ii) influencing the approach adopted by SMEs' leaders (Child \& Hsieh, 2014); (iii) influencing decisions on foreign market selection and entry mode (Ibeh \& Kasem, 2011); (iv) allowing to increase rapidly international commitment (Kalinic, Sarasvathy, \& Forza, 2013); and (v) overcoming resource constraints (Ciravegna et al., 2014). However, many SMEs still face major challenges and obstacles in obtaining the right information and manage it effectively to support the internationalisation processes, thus limiting the creation and accumulation of knowledge about those processes (Hsu et al., 2013; Nguyen et al., 2006). In addition, in the current literature, it is not clear how SMEs assimilate information from their networks and collaboration activities for making better decisions in terms of internationalisation. 
The main objective of this paper is to analyse, synthesise and present a comprehensive systematic literature review (SLR) of the role of information, knowledge and collaboration in internationalisation decisions of SMEs. With this literature review, that is predominantly descriptive and inductive in nature, the authors intended to identify the big challenges for information management as applied to internationalisation processes and the decisions involved in those processes. The review also aimed at analysing how information and knowledge are used and managed for decision-making, as well as how SMEs manage collaboration activities. Thus, the research questions for this SLR are:

RQ1: what is the role of information, collaboration and knowledge in the effectiveness of the SMEs' internationalisation processes?

RQ2: what topics and issues related with information, collaboration and knowledge are considered when SMEs manage their internationalisation processes?

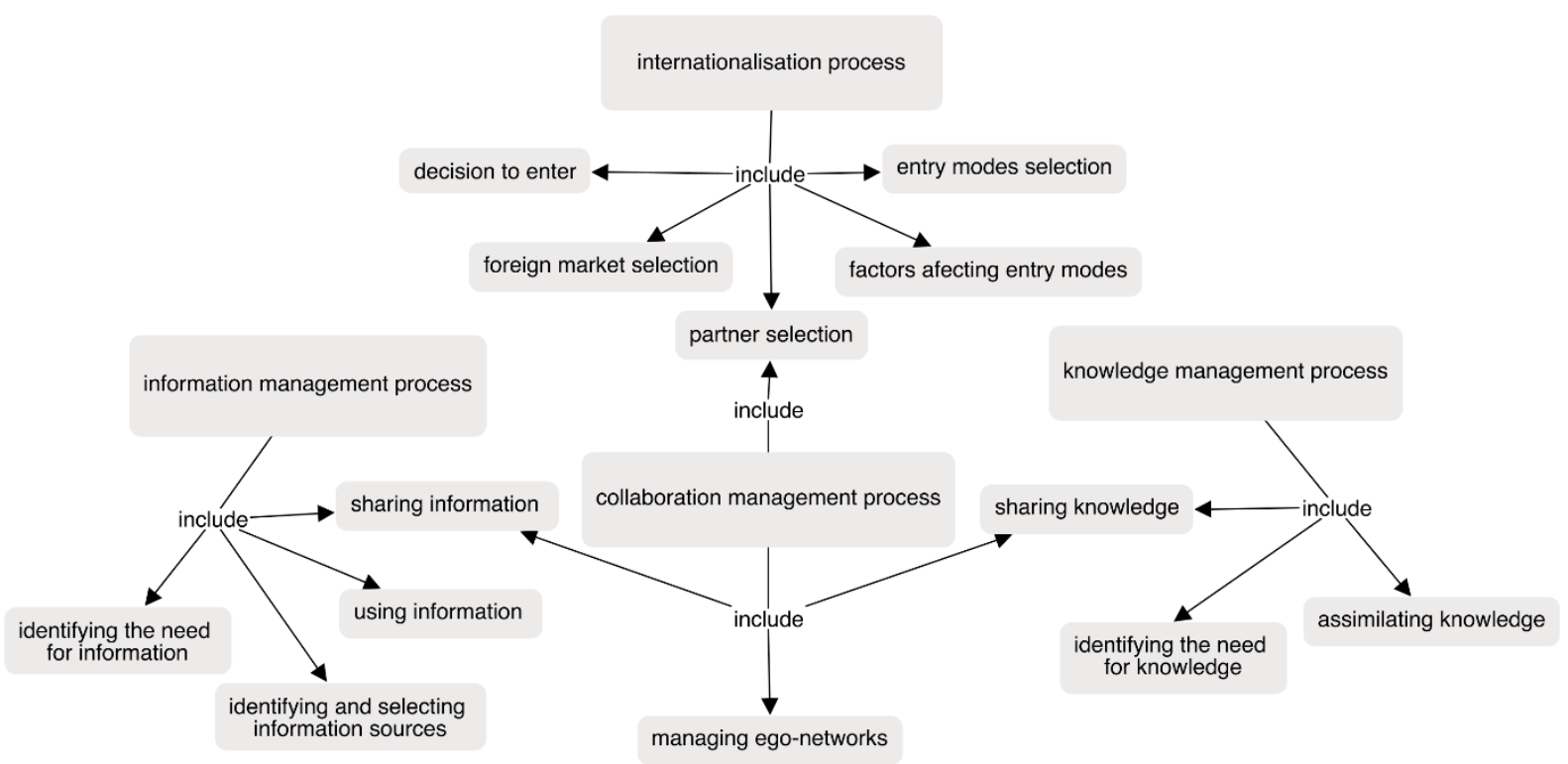

Figure 1 - Main topics related with information, collaboration and knowledge considered in the literature addressing the internationalisation of SMEs

Accordingly, this paper uncovers challenges for researchers in information and knowledge management in designing new artifacts such as collaborative information management platforms fostering innovative models for decision-making and knowledge creation and dissemination as a way to achieve more rational, less uncertain internationalisation processes. Additionally, this SLR contributes to the scientific knowledge on business management and internationalisation by: (i) studying in detail the influence of the above referred thematic areas in the internationalisation of SMEs, with specific focus on decision-making processes; (ii) identifying some of the research gaps in the existing literature; (iii) suggesting directions for future research.

In a preliminary analysis of the selected literature (38 papers) an overarching conceptualisation (a kind of basic ontology) was developed (see Figure 1). It is this conceptualisation that will be used to organise the findings (Section 3) and it will be referred to in the discussion and future research section (Section 4).

The structure of the paper is as follows. Section 2 describes the research methodology applied for this paper, which follows a SLR five-step approach. Section 3 presents the findings of the SLR, organized according to the conceptualisation described in Figure 1. Section 4 discusses the obtained results, presenting meaningful research suggestions and directions for future work. Section 5 and Section 6 provide some limitations and conclusions of the paper. 


\section{Research methodology}

This research followed the systematic literature review (SLR) methodology (Tranfield, Denyer, \& Smart, 2003) as opposed to traditional narrative or descriptive reviews. Using a SLR approach it is possible to create a basic framework for a more in-depth analysis of the literature, adopting a replicable, scientific and transparent process (Tranfield et al., 2003). As suggested by Denyer and Tranfield (2009), a scoping study (exploratory review) of the field was produced prior to the SLR, in order to: (i) clarify the existing basis for the work to be developed; (ii) specify the fit of the proposed SLR into the current body of knowledge; (iii) define concepts; (iv) determine the research questions to be addressed.

Therefore, this paper systematically reviews relevant literature on the role of information, knowledge and collaboration in the effectiveness of making decisions in internationalisation processes of SMEs. The underlying adopted SLR followed a five-step approach, as outlined by Denyer and Tranfield (2009) and Wong, Skipworth, Godsell, and Achimugu (2012):

1) question formulation;

2) locating studies;

3) study selection and evaluation;

4) analysis and synthesis;

5) reporting and using the results.

The following research questions were defined for this study (Step 1): what is the role of information, collaboration and knowledge in the effectiveness of the SMEs' internationalisation processes? what topics and issues related with information, collaboration and knowledge are considered when SMEs manage their internationalisation processes?

The Step 2 concerns the selection of the bibliographic database or search engine, as well as the definition of the search criteria or search strings. The search was tightly aligned with the research questions. Following similar literature reviews (Camargo-Pérez, Carrillo, \& Montoya-Torres, 2014; Hassini, Surti, \& Searcy, 2012; Kamal \& Irani, 2014) two bibliographic databases were used: Web of Science and Scopus. These databases cover a significant proportion of the published material on internationalisation, including the most relevant peer-reviewed journals on the area. Table 1 presents the search strings applied and the number of results obtained.

Table 1 - Search strings and number of results

\begin{tabular}{|c|c|c|c|}
\hline search strings & search field & date of search & number of results \\
\hline \multicolumn{4}{|l|}{ Web of Science } \\
\hline $\begin{array}{l}\text { (decision* OR "decision making" OR "decision- } \\
\text { making") AND (internationali*) AND (information } \\
\text { OR "information management") }\end{array}$ & Topic & 02-03-2015 & 242 \\
\hline $\begin{array}{l}\text { (decision* OR "decision making" OR "decision- } \\
\text { making") AND (internationali*) AND (knowledge } \\
\text { OR "knowledge management") }\end{array}$ & Topic & 02-03-2015 & 238 \\
\hline $\begin{array}{l}\text { (decision* OR "decision making" OR “decision- } \\
\text { making") AND (internationali*) AND (collaborat* } \\
\text { OR "collaborative networks" OR network*) }\end{array}$ & Topic & 02-03-2015 & 175 \\
\hline \multicolumn{4}{|l|}{ Scopus } \\
\hline $\begin{array}{l}\text { (decision* OR “decision making" OR "decision- } \\
\text { making") AND (internationali*) AND (information } \\
\text { OR “information management") }\end{array}$ & $\begin{array}{c}\text { Article title, abstract, } \\
\text { keywords }\end{array}$ & 02-03-2015 & 293 \\
\hline $\begin{array}{l}\text { (decision* OR "decision making" OR "decision- } \\
\text { making") AND (internationali*) AND (knowledge } \\
\text { OR "knowledge management") }\end{array}$ & $\begin{array}{c}\text { Article title, abstract, } \\
\text { keywords }\end{array}$ & 02-03-2015 & 220 \\
\hline $\begin{array}{l}\text { (decision* OR "decision making" OR "decision- } \\
\text { making") AND (internationali*) AND (collaborat* } \\
\text { OR "collaborative networks" OR network*) }\end{array}$ & $\begin{array}{l}\text { Article title, abstract, } \\
\text { keywords }\end{array}$ & 02-03-2015 & 193 \\
\hline
\end{tabular}


The initial search strings using the two bibliographic databases resulted in the identification of 1.361 articles, i.e. 655 for Web of Science and 706 for Scopus. Following the suggestion of Denyer and Tranfield (2009), citation management software packages (Mendeley and EndNote) were used for information management purposes during this step and the following ones.

In the study selection and evaluation (Step 3), some inclusion and exclusion criteria were defined, as a way to select only the more relevant studies to include in the review, i.e. the studies that actually address the research questions. To focus the review on recent studies and recent methodologies and technologies, a 20-year time horizon was first established (1995-2014). Only articles published in peer-reviewed journals in English were considered. Colicchia and Strozzi (2012) argue that by restricting the search only to peer-reviewed journals, the quality control of search results can be enhanced due to the rigorous process to which such articles are subject prior to publication. Some specific research areas were considered for the two bibliographic databases:

- Web of Science:

- International Relations;

- Business Economics;

- Library and Information Science;

- Engineering;

- Operations Research Management Science.

- Scopus:
- Business, Management and Accounting;
- Economics, Econometrics and Finance;
- Engineering;
- Decision Sciences.

This exercise reduced the number of articles for review to 632. After checking duplicates, by using Mendeley and EndNote (first in each search string and after, considering the whole set), titles and abstracts of the selected articles were analysed for relevance. This process was performed by two reviewers to check for inter-rater reliability and agreement. Articles eligible for review had to fulfil four main criteria: (i) articles had to be focused on SMEs (including studies that compared SMEs with multi-national enterprises - MNEs); (ii) articles had to be related to the area of management studies (excluding for example Education and Health Disciplines); (iii) articles had to be empirical (qualitative and quantitative studies) rather than theoretical or conceptual; (iv) articles had to be focused on the influence of information, knowledge and collaboration in internationalisation processes of SMEs, with specific emphasis on decision-making processes. At this stage, the number of articles for analysis was reduced to 77.

Finally, in the last stage a more detailed analysis of the 77 articles was made, with the two reviewers performing a full text review. Articles from 1995 to 2004 were first excluded, since they were only representative of a very small percentage of the sample, and also to perform a more focused review and analysis, giving priority to more recent studies and consequently reducing the time horizon from 20 to 10 years (2005-2014). Through the full text review, some other articles were excluded as they were not in accordance with the specific research focus of this study, this allowing to reduce the number of final articles for analysis and synthesis to 38, as listed in Table 2.

Table 2 - Summary of the systematic review articles selection and evaluation

\begin{tabular}{|c|c|c|c|c|}
\hline & Search 1 & Search 2 & Search 3 & Total \\
\hline \multicolumn{5}{|l|}{ Bibliographic database analysis } \\
\hline Web of Science & 242 & 238 & 175 & 655 \\
\hline Scopus & 293 & 220 & 193 & 706 \\
\hline \multicolumn{5}{|l|}{ Inclusion/exclusion criteria } \\
\hline \multicolumn{5}{|l|}{ Web of Science } \\
\hline Date range & 213 & 225 & 171 & 609 \\
\hline Document type & 175 & 190 & 135 & 500 \\
\hline Subject area & 162 & 172 & 118 & 452 \\
\hline Language & 148 & 161 & 112 & 421 \\
\hline
\end{tabular}




\begin{tabular}{|l|c|c|c|c|}
\hline Scopus & \multicolumn{1}{|c|}{6} \\
\hline Date range & 279 & 215 & 188 & 682 \\
\hline Document type & 166 & 166 & 140 & 472 \\
\hline Subject area & 56 & 97 & 69 & 222 \\
\hline Language & 53 & 91 & 67 & 211 \\
\hline & 201 & 252 & 179 & 632 \\
\hline TOTAL & 175 & 199 & 150 & 524 \\
\hline After checking duplicates (in each search) & \multicolumn{5}{|c|}{706} \\
\hline After checking duplicates (in all searches) & \multicolumn{5}{|c|}{38} \\
\hline Title and abstract analysis & \multicolumn{5}{|c|}{} \\
\hline After detailed article analysis &
\end{tabular}

The content of each paper was analysed by the reviewers in Step 4, extracting and storing information and cross tabulating the studies, in order to identify key issues. Using two reviewers, when their interpretations and findings are compared, it is possible to minimize errors, as well as to resolve any differences, thus producing a more robust data set (Denyer \& Tranfield, 2009). A summary of the information contained in each of the 38 articles was then prepared using a data extraction form organized with relevant categories, such as research methodologies used and key findings / contributions. This information was used to systematize, structure, and tabulate the data.

The current paper represents the formal presentation of the results to the academic community (Step 5). The remaining content of the paper reports the findings of the present study in a thematic way.

\section{Findings}

Findings were grouped into four categories, as a way to better understand the fundamentals of each process under analysis and following the conceptualisation of Figure 1: (i) decision-making process; (ii) information management process; (iii) knowledge management process; (iv) collaboration management process.

\subsection{Decision-making process}

Internationalisation is a complex process dealing with a large variety of decisions (Santos-Alvarez \& GarcíaMerino, 2010). Andersson (2011) states that decision-making processes are complicated, involving interactions with other entities, both inside and outside the firm. An internationalisation process is typically composed by four key constructs (London, 2010): market selection, decision to enter, entry modes, and factors affecting entry modes. Crick and Spence (2005) suggest that no single theory can fully explain decisions in internationalisation processes. In fact the SLR performed in this work identified different types of decisions made in this context.

\subsubsection{Decision to internationalise}

As stated by Pinho (2007), different theories and conceptual frameworks have been used to explain the initial decision to internationalise, such as the Uppsala internationalisation model (Johanson \& Vahlne, 1977), the resource-based view (Barney, 1991), the network approach to internationalisation (Coviello \& Munro, 1997), and the Dunning eclectic paradigm (Dunning, 1988). Findings from the analysed articles show that the decision to internationalise can result from different internal and external factors, such as the entrepreneurial orientation of the decision-maker (Kollmann \& Christofor, 2014), the decision-maker's proficiency in foreign languages (Cannone \& Ughetto, 2014), and the existing and new relational contacts, relationships, collaborations and networks (Castellacci, 2014; Ibeh \& Kasem, 2011; Xie \& Amine, 2009). For instance, in a quantitative study with 871 Dutch SMEs, Hessels and Terjesen (2010) found that the decision-maker's perception of the increased international presence of their network members (competitors, customers and suppliers) explains the decision to internationalise. Based on the research of Knight and Liesch (2002), Casillas, Acedo, and Barbero (2010) suggest that SMEs need to own a good knowledge base from various sources (supra-organisational, organisational and individual) in order to decide to go international, i.e. another decision must be made concerning the collection of knowledge related to the start of the international activity. 


\subsubsection{Entry mode selection}

Another fundamental decision is the entry mode selection, described by Pinho (2007) and Francioni, Musso, and Vardiabasis (2013) as one of the most critical decisions in internationalisation strategies. Different entry modes and strategies were described in the analysed articles. However, to better illustrate these modes the classification of Root (1994) was used, with each mode requiring different levels of investment and commitment:

- Export entry mode

$\circ$ exportation only

- Contractual entry mode

- transfer of technological or human skills

$\circ$ strategic alliances

- subcontracting

- Investment entry mode

$\circ$ joint-venture

- sole venture

$\circ$ foreign direct investment

The main goal of this paper is not to describe these modes in detail, but rather identify those modes that have been addressed by the SLR, and understand some important factors that have influence in these decisions. Therefore, the entrepreneurial orientation of the decision-maker, as well as his/her networking capacity, were again some factors that have a positive influence in first entry mode decisions of SMEs (Ibeh \& Kasem, 2011; Kaur \& Sandhu, 2013; Loane \& Bell, 2006) and subsequent foreign entries are better explained by accumulated knowledge and experience (Peng, Yang, \& Liang, 2011). The study of Hessels and Terjesen (2010) also shows that the decisionmaker's perception of favourable conditions for accessing knowledge, technology, production costs and capital in the home market explain the choice of entry mode (in alignment with the resource dependency theory). For Kaur and Sandhu (2013) entry mode decisions seems to be dependent on the nature and condition of the industry in which the firm operates.

\subsubsection{Foreign market selection}

Another critical decision considered in the reviewed literature is the foreign market or host country selection (Francioni et al., 2013; Ojala \& Tyrväinen, 2008). Social and business relationships and network partners seem to be the most important factors influencing market selection decisions (Aspelund \& Butsko, 2010; Ibeh \& Kasem, 2011; Loane \& Bell, 2006). However, an exception is reported by Ojala (2009) who states that the decision of Finnish software SMEs to enter the Japanese market was based on strategic reasons rather than simply following network relationships. This happened due to the fact that their products were niche products, and to the existence of numerous IT-based manufacturing and target customers in Japan. For example, one company developed technology for videogames, and Japan was the first target since it represents the most advanced market in the field.

In a different direction, the empirical study of Francioni et al. (2013) presents cases when SMEs from the mechanical sector decided to change markets or entry modes. The main result is that these changes do not only come from social and business relationships, but also from proactive and reactive characteristics of the decisionmaker.

\subsubsection{Collaboration decisions and commitment decisions}

Two other types of decisions were identified concerning: (i) collaboration; and (ii) commitment. According to Spence, Manning, and Crick (2008), firms decide to collaborate and choose vertical or horizontal collaboration forms depending on the motives for establishing an alliance and on the network partners' positions in the value chain. On one hand, Castellacci (2014) found that SMEs could decide to engage in collaboration with foreign partners to support their international activity. The relative sizes of the enterprise and of the foreign partner can 
influence the firm's decision to engage in international collaborations. On the other hand, Spence et al. (2008) found out that when alliances occur, the strategic focus is on decisions for developing and managing these collaborations rather than focusing on decisions about which market to enter.

In terms of commitment decisions, Camuffo, Furlan, Romano, and Vinelli (2007) are the only authors addressing in detail this type of decisions. The authors conclude that the decision to commit further resources to foreign operations, and the organisation of international business activities, are affected by market knowledge and by the amount of resources already assigned to a specific country. Furthermore, they also found out that local business networks have a clear influence on the decision of firms to make higher commitment decisions.

\subsubsection{Decision mode}

Child and Hsieh (2014) present a very detailed study on the different decision modes that managers may follow when they internationalise. These authors define four main decision modes, ranging from a low to a high level of planning and rationality: (i) reactivity, where decision-makers are more conservative and take decisions by responding to immediate situational demands or environmental changes (Covin, 1991); (ii) incrementalism, often mentioned as "muddling through" (Lindblom, 1959), where decision-makers make successive limited comparisons of possible actions, or limited increments from existing conditions, to avoid negative consequences; (iii) bounded rationality, as introduced by Simon (1955), where decision-makers are more rational and goal-directed but have some limitations to secure and process relevant information; (iv) real options reasoning, where decision-makers have a rational way of reducing risks associated with both incomplete information and uncertainty, making comparisons between alternatives (Adner \& Levinthal, 2004).

The decision mode to be adopted has implications in terms of the required information, and also the other way around, i.e. reactivity and incrementalism modes may require uncodified and relatively narrow information while more planned decision modes (bounded rationality and real options reasoning) may require more codified and wide information. In addition these authors suggest that reactive or incremental decision modes are more related with traditional SMEs whereas knowledge-base or knowledge intensive SMEs tend to adopt bounded rationality and real options reasoning modes. However, in most of the cases it is not clear what specific decision modes were adopted by SMEs' decision-makers. So, for analysis purposes, a distinction was made between unplanned decisions, related with reactivity and incrementalism, and planned decisions, related with bounded rationality and real options reasoning (Table 3).

Table 3 - Decision modes found in the SLR

\begin{tabular}{|c|c|c|}
\hline Decision modes & References & Empirical findings \\
\hline \multirow[t]{4}{*}{$\begin{array}{l}\text { Unplanned } \\
\text { decisions }\end{array}$} & $\begin{array}{l}\text { (Aspelund \& Butsko, 2010) } \\
\text { (Andersson, 2011) } \\
\text { (Ibeh \& Kasem, 2011) } \\
\text { (Hultman, Johnsen, Johnsen, } \\
\text { \& Hertz, 2012) } \\
\text { (Schweizer, 2012) }\end{array}$ & $\begin{array}{l}\text { SMEs may not follow a systematic and linear pattern for making } \\
\text { internationalisation decisions. Instead of making planned decisions, } \\
\text { SMEs prefer to trust in their knowledge and intuition (Andersson, } \\
\text { 2011; Schweizer, 2012) or social and business relationships } \\
\text { (Aspelund \& Butsko, 2010; Hultman et al., 2012; Ibeh \& Kasem, } \\
\text { 2011). }\end{array}$ \\
\hline & (Crick \& Spence, 2005) & $\begin{array}{l}\text { Some firms' internationalisation takes place as a reaction to } \\
\text { opportunities provided by existing networks and serendipitous } \\
\text { encounters. }\end{array}$ \\
\hline & $\begin{array}{l}\text { (Mockaitis, Vaiginienè, \& } \\
\text { Giedraitis, 2006) }\end{array}$ & $\begin{array}{l}\text { The decision of the analysed SMEs to internationalise into foreign } \\
\text { markets does not result from any strategic or planned activity. }\end{array}$ \\
\hline & (Spence et al., 2008) & $\begin{array}{l}\text { Collaborations tend to be managed informally, without planning all } \\
\text { decisions but rather keeping the communication channels open at all } \\
\text { levels. }\end{array}$ \\
\hline \multirow[t]{2}{*}{$\begin{array}{l}\text { Planned } \\
\text { decisions }\end{array}$} & (Schweizer, 2012) & $\begin{array}{l}\text { The increased experience and knowledge obtained through a learning } \\
\text { process lead to more rational and planned decision-making. }\end{array}$ \\
\hline & $\begin{array}{l}\text { (Fletcher \& Prashantham, } \\
\text { 2011) }\end{array}$ & $\begin{array}{l}\text { Knowledge is an important key to more formal decisions. Rapidly } \\
\text { internationalising SMEs adopted high levels of formality in } \\
\text { assimilating knowledge, mainly using formal planned events to share } \\
\text { knowledge and to codify tacit into explicit knowledge. }\end{array}$ \\
\hline
\end{tabular}




\begin{tabular}{|l|l|l|}
\hline & (Rodriguez et al., 2010) & $\begin{array}{l}\text { Risks in internationalisation can be avoided or reduced if a company } \\
\text { adopts more planned decision-making strategies with the } \\
\text { development of a set of standard guidelines, policies, procedures and } \\
\text { methodologies in each internationalisation project. }\end{array}$ \\
\cline { 2 - 3 } (Ojala, 2009) & $\begin{array}{l}\text { When SMEs internationalise, they may not passively follow their } \\
\text { networks to foreign markets (reactive strategy). Instead, they may } \\
\text { consider the adoption of more active strategies to seek for } \\
\text { opportunities for going international, with the development of new } \\
\text { networks or using the existing ones. }\end{array}$ \\
\hline
\end{tabular}

\subsection{Information management process}

It is important to make a clear distinction between information and knowledge in this paper. Although they are both critical in the SMEs' internationalisation process, they influence it in distinct ways (Knight \& Liesch, 2002). Information is inextricably antecedent to knowledge (Dretske, 1981). In one way, information is defined as structured and understandable data, organised in order to be a useful input to knowledge (Child \& Hsieh, 2014). Moreover, knowledge is created from information and is about beliefs and commitment, validated in a person's perception or expectation for taking actions (Nonaka \& Takeuchi, 1995). Grant (1991) considers that to ensure information is useful, firms need to create models and standards of behaviour converting tacit organisational knowledge into explicit knowledge.

\subsubsection{Need for information}

Many SMEs still face difficulties in internationalisation processes, and the lack of information has been identified as one main obstacle in those processes (Hsu et al., 2013; London, 2010; Sommer \& Haug, 2011). Decision-makers need to search and acquire information, in order to identify market opportunities in foreign countries. For this purpose, large amounts of information are required to compensate the lack of prior knowledge and experience, and as a way to reduce internationalisation uncertainties (Xie \& Amine, 2009). Therefore, due to the imperfect access to information, entering foreign markets can represent a significant risk for SMEs, with extra costs for collecting information and for seeking and evaluating partnerships (Hessels \& Terjesen, 2010).

When SMEs move into new international markets, information processing increases and becomes more complex (Hsu et al., 2013). Aspelund and Butsko (2010) found that some decision-makers used to randomly select foreign market locations, due to a lack of experimental market knowledge on internationalisation, as well as a lack of organisational capabilities to process information. SMEs in the study of Santos-Alvarez and García-Merino (2010) although interested in internationalisation, did not allocate the right efforts to gather information, thus limiting their internationalisation process. Another important issue raised by some of the analysed articles is the poor development of suitable information technology tools, to predict and evaluate problems arising from specific destination countries (Rodriguez et al., 2010).

\subsubsection{Information sources, information sharing and information subjects}

Different sources of information are used by SMEs in internationalisation processes, ranging from social and business relations to previous international experiences (Santos-Alvarez \& García-Merino, 2010). Xie and Amine (2009) found that decision-makers typically choose their information sources as a function of their perceived utility. Firms can use internal and external sources to develop new market-specific knowledge and learning (Akerman, 2014): they can learn from internal sources through direct experience in their operations and using internally stored information, and/or from external sources by using the experience of others and externally available information.

The increasing availability and diversity of information sources, suggest that companies consider more rational decision modes when comparing alternative strategies (Child \& Hsieh, 2014). Additionally, based on previous studies, Rodriguez et al. (2010) propose the use of formal (market research) and informal techniques (relying on 
gatekeepers) to gather information from different sources. However, the SLR suggests that SMEs tend to rely more on their networks to gather and share information about foreign markets from several sources.

Undoubtedly, networks have been playing an important part in the decision-making processes (Aspelund \& Butsko, 2010; Cannone \& Ughetto, 2014). Casillas et al. (2010) suggest that collective knowledge is more important in internationalisation due to the individual difficulties of SMEs in searching information. Information shared in networks also increases the commitment in foreign markets (Hultman et al., 2012) and reduces information asymmetry (Child \& Hsieh, 2014). Information is shared through firms' networks, both at the social and business level, which include customers, suppliers, competitors, family and friends (Chen, 2011; Ibeh \& Kasem, 2011; Peng et al., 2011; Xie \& Amine, 2009). Moreover, Xie and Amine (2009) suggest that networks, mainly social networks, must be properly recognized as primary sources of information, knowledge, and fast learning.

Information sharing was found as being of great importance to the development of trust and synergy to sustain collaboration relationships (Spence et al., 2008). Information can be used for evaluating with whom to contact, who has what, and how much of it is relevant to decision-making (Child \& Hsieh, 2014). Finally, Spence et al. (2008) suggest that successful collaborative ventures require information sharing and not information control, based on a collaboration-based mentality instead of a competition-based one.

The main subject that SMEs look for within their information sources was about foreign market conditions (Cannone \& Ughetto, 2014; Ibeh \& Kasem, 2011). Other information subjects identified were the following: attractiveness of specific locations and host countries (Aspelund \& Butsko, 2010; Peng et al., 2011; Xie \& Amine, 2009); internationalisation strategies and the internationalisation process itself (Peng et al., 2011; Santos-Alvarez \& García-Merino, 2010; Xie \& Amine, 2009); obstacles faced in internationalisation processes (Santos-Alvarez \& García-Merino, 2010; Xie \& Amine, 2009); support programmes for helping firms to internationalise (SantosAlvarez \& García-Merino, 2010); experiences and knowledge about foreign industries (Chen, 2011; Peng et al., 2011); and marketing opportunities (Xie \& Amine, 2009).

\subsubsection{Importance of decision-makers' characteristics in information management}

The analysis of the literature shows that decision-makers have experiences, backgrounds, and personal characteristics (Hsu et al., 2013) that form their cognitive perspectives influencing the way how they identify, seek and process information. With this cognitive basis they influence decisions by directing their vision, filtering their perceptions, and interpreting information. Table 4 show these characteristics and how they influence the decisionmakers access and use of information.

Table 4 - Decision-makers' characteristics that influence information management in internationalisation

\begin{tabular}{|l|l|l|}
\hline Characteristics & References & Empirical findings \\
\hline Age & (Hsu et al., 2013) & $\begin{array}{l}\text { Age of decision-makers is linked to the capacity for processing and } \\
\text { analysing information. }\end{array}$ \\
\hline Tenure & (Hsu et al., 2013) & $\begin{array}{l}\text { Tenure is an indicator of a decision-maker's ability to gather and } \\
\text { process information. }\end{array}$ \\
\cline { 2 - 3 } & $\begin{array}{l}\text { Long-tenured top-management-teams (TMTs) of firms can provide } \\
\text { competitive advantages in internationalisation due to their more } \\
\text { accurate shared cognitive structure about international environments, } \\
\text { their capacity of filtering and interpreting information more clearly, } \\
\text { and their better assessment of organisational resources and capabilities. }\end{array}$ \\
\hline $\begin{array}{l}\text { Information } \\
\text { capabsility }\end{array}$ & $\begin{array}{l}\text { Information processing capabilities of decision-makers have positive } \\
\text { effects in the internationalisation performance. Decision-makers with } \\
\text { high information processing capabilities, perform better when doing } \\
\text { business in an international environment. }\end{array}$ \\
\hline $\begin{array}{l}\text { International } \\
\text { experience }\end{array}$ & (Cui, Li, \& Li, 2013) & $\begin{array}{l}\text { Managerial international experience enhances the ability of a SME to } \\
\text { process foreign market information. }\end{array}$ \\
\hline
\end{tabular}




\begin{tabular}{|l|l|l|}
\hline & (Child \& Hsieh, 2014) & $\begin{array}{l}\text { A larger international experience can improve the decision-makers' } \\
\text { capacity in using enhanced network information to adopt more rational } \\
\text { decision modes. }\end{array}$ \\
\cline { 2 - 3 } & (Chen, 2011) & $\begin{array}{l}\text { International experience facilitates the collection of information from } \\
\text { external relationships, thus reducing the anxiety of operating under } \\
\text { complex and ambiguous conditions. }\end{array}$ \\
\hline $\begin{array}{l}\text { Organisational } \\
\text { memory }\end{array}$ & $\begin{array}{l}\text { Organisational memory related with international experience, kept in } \\
\text { the minds of decision-makers of an organisation, can be further } \\
\text { accessed to build knowledge structures, and to guide information } \\
\text { processing and decision-making for future entries into foreign markets. }\end{array}$ \\
\hline
\end{tabular}

\subsection{Knowledge management process}

Knowledge has been considered as a key resource for SMEs to pursue better internationalisation processes (Fletcher \& Prashantham, 2011). Several theories on internationalisation have emphasised the relevance of knowledge, such as the Uppsala internationalisation model (Johanson \& Vahlne, 1977), the upper echelons theory (Hambrick \& Mason, 1984), theories of international entrepreneurship (McDougall \& Oviatt, 2000), and the knowledge-based view (Grant, 1996). A detailed description of the role of knowledge in these theories is not within the scope of this article.

\subsubsection{Need for knowledge}

Based on the analysed literature, knowledge in internationalisation can be understood as the interpretation of information and beliefs, from different experiences (by individual managers, firms, and networks), thus creating a learning process for making better decisions (Akerman, 2014; Casillas et al., 2010). In fact, previous works had shown that internationalisation decisions are the result of a process of acquisition, assimilation, and interpretation of knowledge about foreign markets and international strategies (Knight \& Liesch, 2002). This learning process through a knowledge base, allows SMEs to have favourable attitudes for internationalisation (Casillas et al., 2010), to make more rational decisions (Schweizer, 2012), and to reduce uncertainty (Mockaitis et al., 2006). From a different point of view, the results of Child, Duarte, Tanure, and Rodrigues (2012) show the critical role that knowledge has in the decision of a company to retain or release executives after performing an international acquisition. The retention seems to be mainly justified by the knowledge the firms own, in order to avoid losses of critical knowledge that is useful for the business.

Undoubtedly SMEs need knowledge to support their internationalisation processes and the lack of this important element represents one of the main obstacles for SMEs wanting to go international (Hsu et al., 2013; Sommer \& Haug, 2011; Zucchella \& Servais, 2012). Rodriguez et al. (2010) found that many SMEs were not capable of neither predicting risks nor turning internationalisation into a sustainable competitive advantage, mainly due to the lack of suitable tools for managing knowledge acquired from previous experiences. Židonis (2007) interviewed some members of a Lithuanian company, and found that knowledge is used to create beliefs on markets, but incomplete, fragmented or contradictory knowledge may result in a system of unrealistic assumptions about international environments.

\subsubsection{Knowledge nature and knowledge assimilation}

Some studies show that knowledge assimilated by SMEs in internationalisation processes is both tacit and explicit in nature (Child et al., 2012; Fletcher \& Prashantham, 2011; Sommer \& Haug, 2011). Tacit knowledge is subjective and hard to formalise, being embedded in individuals and relationships, in the form of beliefs, perspectives and ideals (Nonaka, 1994). In general this is quite valuable for firms, but this type of knowledge is obviously more difficult to be measured and expressed (Child et al., 2012). On the contrary, explicit knowledge is more objective information that can be easily stored, articulated and transferred, through formal and systematic procedures (Nonaka, 1994). The study of Camuffo et al. (2007) shows that due to its high complexity and tacitness, the knowledge involved in an internationalisation process negatively impacts the process of transferring it abroad. This leads SMEs to opt for entry modes with low levels of investment and commitment, such as subcontracting. Fletcher and Prashantham (2011) also identify difficulties for SMEs to assimilate tacit knowledge. Moreover, Child et al. (2012) concludes that less codified knowledge (tacit knowledge) increases the probability of an acquirer company to retain executives after the acquisition. The main justification is that when a new acquirer/owner 
directly controls and manages the company, knowledge will be of a more tacit nature and less codified, and therefore retaining executives because of their extensive tacit knowledge seems to be the best option.

The assimilation of knowledge is viewed as a key feature for SMEs wanting to internationalise (Fletcher \& Prashantham, 2011). Empirical results by Akerman (2014) confirm that the strategies on how to acquire knowledge significantly influence the outcomes of the SMEs' international operations. By accumulating knowledge, firms can better understand foreign cultures, markets, and operations, thus improving the quality of decision-making (Camuffo et al., 2007). For instance, Cui et al. (2013) concluded that the accumulation of knowledge about foreign markets allows SMEs to reduce uncertainty and consequently increase the probability of future entries in similar markets. Findings by Fletcher and Prashantham (2011) indicate that firms often adopt high levels of formality in sharing and assimilating knowledge, such as formal planned events for sharing both explicit and tacit knowledge and the codification of tacit to explicit knowledge. However, Židonis (2007) states that knowledge accumulation is more complicated than expected, with a case studied showing that the accumulated knowledge was not relevant for the internationalisation process.

\subsubsection{Knowledge types}

Distinct types of knowledge have been highlighted in the literature of firms' internationalisation processes. In fact different classifications have been applied to describe the type of knowledge used by SMEs in their studies. However, in many cases, articles adopted different terms to describe similar types of knowledge. Based on these references and on some other references (Fletcher \& Harris, 2012; Mejri \& Umemoto, 2010), a knowledge classification was therefore established to create a more coherent structure for the analysis (Table 5):

- Market knowledge: objective or explicit information about foreign markets, e.g. market size, labour costs and skills, consumer behaviour, local competitors, payment conditions, regulations, language, norms (Camuffo et al., 2007; Mejri \& Umemoto, 2010). It is clear that market knowledge requires activity on the market, but it can specifically be assimilated in an explicit form through cognitive learning (Basly, 2007). Barriers in languages, culture and business practices are overcome and the chance to internationalise early is enhanced due to decision-makers with prior market knowledge (Cannone \& Ughetto, 2014).

- $\quad$ Experiential: knowledge that can only be learned through personal experience (Mejri \& Umemoto, 2010). Experiential knowledge can come from direct involvement in internationalisation processes (internationalisation knowledge) or from network partners (network knowledge), providing an input for comparing previous international experiences with newly encountered ones (Child \& Hsieh, 2014).

- Internationalisation knowledge: knowledge accumulated with international experience (Fletcher \& Harris, 2012) and knowledge of the existence of opportunities for exploitation (Mejri \& Umemoto, 2010). Internationalisation knowledge from international activities can be the understanding about which knowledge is needed in specific situations in an international context (Akerman, 2014).

- Network knowledge: knowledge obtained from social and business networks to facilitate internationalisation (Mejri \& Umemoto, 2010). Using network knowledge, firms gain access to new resources and learn new skills with their network partners, this facilitating foreign market entries without requiring many assets (Kaur \& Sandhu, 2013).

- Technological knowledge: knowledge that provides specific advantages to firms, such as innovative and unique products or services, which are transferable across borders (Fletcher \& Harris, 2012). To run foreign operations successfully, firms must transfer some technological knowledge (techniques, methods and designs) from home to the host country (Camuffo et al., 2007).

Table 5 - Knowledge types found in the SLR

\begin{tabular}{|l|l|l|}
\hline Knowledge types & References & Empirical findings \\
\hline Market knowledge & $\begin{array}{l}\text { (Aspelund \& Butsko, } \\
2010)\end{array}$ & $\begin{array}{l}\text { Decision-makers randomly select locations to internationalise due to } \\
\text { lack of market knowledge, as well as lack of organisational } \\
\text { capabilities to process such information. }\end{array}$ \\
\cline { 2 - 3 } & (Akerman, 2014) & $\begin{array}{l}\text { Case studies show that the assimilation of market knowledge paves } \\
\text { the way for additional sales in foreign markets and for the acquisition } \\
\text { of new customers. }\end{array}$ \\
\hline
\end{tabular}




\begin{tabular}{|c|c|c|}
\hline & (Pinho, 2007) & $\begin{array}{l}\text { Market knowledge, together with the SMEs' international experience, } \\
\text { innovation capacity, and market potential for growth are seen as key } \\
\text { predictors for choosing an equity-entry mode. }\end{array}$ \\
\hline & (Mockaitis et al., 2006) & $\begin{array}{l}\text { Most of the SMEs do not consider market knowledge as important, } \\
\text { mainly because of foreign orders fulfilment in their home markets. } \\
\text { Consequently, investments to learn about foreign markets are not } \\
\text { viewed as necessary. }\end{array}$ \\
\hline \multirow[t]{4}{*}{$\begin{array}{l}\text { Internationalisation } \\
\text { knowledge }\end{array}$} & (Camuffo et al., 2007) & $\begin{array}{l}\text { Experiential knowledge, mainly internationalisation knowledge, plays } \\
\text { a critical role in the incremental process of supplier and production } \\
\text { network internationalisation. }\end{array}$ \\
\hline & (Cui et al., 2013) & $\begin{array}{l}\text { Managers' decisions on new foreign direct investments are strongly } \\
\text { based on knowledge obtained from the firm's prior } \\
\text { internationalisation knowledge. }\end{array}$ \\
\hline & (Basly, 2007) & $\begin{array}{l}\text { Although finding that internationalisation knowledge has a positive } \\
\text { influence in the internationalisation degree of the firm, the } \\
\text { conservatism of the family SME (firm's type) analysed does not show } \\
\text { significant influence on the level of internationalisation knowledge. } \\
\text { The only influence of conservatism on internationalisation knowledge } \\
\text { is on the decisional dimension of independence orientation (a } \\
\text { consequence of the family long-term commitment to the business). }\end{array}$ \\
\hline & (Židonis, 2007) & $\begin{array}{l}\text { The lack of knowledge is not an obstacle for the internationalisation } \\
\text { process of the firm due to its "trial-and-error" international behaviour. }\end{array}$ \\
\hline \multirow[t]{4}{*}{$\begin{array}{l}\text { Network } \\
\text { knowledge }\end{array}$} & (Andersson, 2011) & $\begin{array}{l}\text { Network knowledge is important for fast international expansion and } \\
\text { growth. }\end{array}$ \\
\hline & (Casillas et al., 2010) & $\begin{array}{l}\text { Knowledge originated from the experiences of other businesses is the } \\
\text { one with stronger influence on the intention of SMEs to export. } \\
\text { Therefore, collective knowledge has a more intense influence than the } \\
\text { individual knowledge, as a motivation for starting internationalisation } \\
\text { processes. }\end{array}$ \\
\hline & (Peng et al., 2011) & $\begin{array}{l}\text { Knowledge sharing in networks provides firms with necessary } \\
\text { country-specific experience, facilitating decision-making of initial and } \\
\text { subsequent investments in host countries. }\end{array}$ \\
\hline & (Loane \& Bell, 2006) & $\begin{array}{l}\text { A large proportion of the firms studied actively uses networks to } \\
\text { develop their knowledge about foreign markets and improve } \\
\text { international competitiveness. Such network knowledge influences } \\
\text { market selection and entry decisions, overcoming resource and } \\
\text { knowledge deficiencies. }\end{array}$ \\
\hline \multirow[t]{3}{*}{$\begin{array}{l}\text { Technological } \\
\text { knowledge }\end{array}$} & $\begin{array}{l}\text { (Hessels \& Terjesen, } \\
2010)\end{array}$ & $\begin{array}{l}\text { SMEs are more likely to export using direct modes if located in home } \\
\text { markets with favourable conditions to access to technological } \\
\text { knowledge. }\end{array}$ \\
\hline & (Camuffo et al., 2007) & $\begin{array}{l}\text { Decisions on the internationalisation of supplier and production } \\
\text { networks are mainly influenced by the nature of the technological } \\
\text { knowledge involved. }\end{array}$ \\
\hline & (Sedoglavich, 2012) & $\begin{array}{l}\text { Results suggest that international activities are mainly based on firms' } \\
\text { technological capabilities and technological knowledge. However, } \\
\text { this technological knowledge may also constrain the development of } \\
\text { future international strategies if the firms' technology is not affected } \\
\text { by their foreign strategies. }\end{array}$ \\
\hline
\end{tabular}

\subsubsection{Knowledge-intensive firms}

SMEs can also be classified according to the role of knowledge in their internationalisation activities (Child \& Hsieh, 2014). The most common terms applied in the analysed articles are knowledge-intensive or knowledgebased firms. These cases are mainly SMEs from the software industry, with all authors agreeing that knowledgeintensive firms tend to differ from more traditional firms. Decisions to internationalise are largely dependent on networks and collaboration to improve foreign market entries (Torkkeli, Puumalainen, Saarenketo, \& Kuivalainen, 2012). Ojala and Tyrväinen (2008) add that successful knowledge-intensive SMEs develop their network relationships and focus their resources, in order to enter the leading markets for their products. Despite of this, Ibeh and Kasem (2011) found a lack of studies in the literature on the internationalisation of knowledge-based or knowledge-intensive SMEs from developing countries. 


\subsection{Other aspects of the collaboration management process}

Many aspects of the collaboration management process in internationalisation have already been described along the previous sections, such as collaboration decisions (Section 3.1.4), decision modes (Section 3.1.5) and the process of information sharing in collaborations (Section 3.2.2). This section briefly presents some other important issues to consider in this process.

There is growing evidence in the analysed literature that SMEs need to collaborate with other entities to gain competitive advantage in internationalisation. As stated by Ibeh and Kasem (2011), companies are not isolated entities but rather actors in markets, depicted as social and business relationships systems. Loane and Bell (2006) reinforce this idea, suggesting that SMEs must prioritise the development of networks and collaborations and adopt assiduous and strategic ways of pursuing such opportunities. Castellacci (2014) points out that international collaboration in services firms is an important factor to foster decisions to enter foreign markets.

Rather than only focusing on networks to share information and knowledge, Spence et al. (2008) present a different level of collaboration, namely "collaborative ventures". This type of collaboration is established between firms, to complement core competencies, thus providing complementary and attractive products or services to markets, and increasing competitive advantages to internationalise. Collaborative ventures establish what is considered in other research areas as collaborative networks (Camarinha-Matos \& Afsarmanesh, 2005), forming vertical alliances (alliances with upstream and downstream partners), horizontal alliances (relationships with competitors), or even collaboration forms with firms from different sectors (Spence et al., 2008). Based on the analysed articles, and depending on the situations, different intermediaries can be used to form collaborations (see Table 6).

Table 6 - Intermediaries to form collaborations in internationalisation

\begin{tabular}{|l|l|}
\hline Knowledge types & References \\
\hline $\begin{array}{l}\text { Local partners (distributors, subcontractors and } \\
\text { customers) }\end{array}$ & (Cannone \& Ughetto, 2014; Hultman et al., 2012) \\
\hline Competitors & (Casillas et al., 2010; Malik, 2012) \\
\hline $\begin{array}{l}\text { Managers' contacts from previous jobs or } \\
\text { experiences }\end{array}$ & (Andersson, 2011; Zucchella \& Servais, 2012) \\
\hline External parties & (Aspelund \& Butsko, 2010; Peng et al., 2011) \\
\hline Foreign firms & (Castellacci, 2014; Ibeh \& Kasem, 2011) \\
\hline Institutional agencies and government bodies & (Child \& Hsieh, 2014; Santos-Alvarez \& García-Merino, 2010) \\
\hline Personal contacts, relatives and friends & (Kaur \& Sandhu, 2013; Kollmann \& Christofor, 2014) \\
\hline Strategic allies and affiliated companies & (Peng et al., 2011; Torkkeli et al., 2012) \\
\hline
\end{tabular}

The success of collaborative ventures and alliances is highly dependent on creating value for all the parties, and it can be measured as a function of choosing the right partners, managing the partner relationship and accumulating relational capital (Townsend, 2003). So, in addition to collaborative strategic decisions that need to be made in collaboration, partner selection is another important decision. Spence et al. (2008) found that this choice is crucial for the success of the partnership, and some of the main partner selection criteria are international leverage, knowledge and access to foreign markets, and technology expertise.

\section{Discussion and research agenda}

This paper presents a SLR using articles about the roles of information, knowledge and collaboration in the process of decision-making in the internationalisation of SMEs. Some important issues that have emerged from this review are discussed in this section. In addition, it was possible to identify a number of gaps in existing empirical knowledge, thus providing suggestions and directions for future research. The discussion will follow the conceptualisation described in Figure 1.

First, in what concerns a SME decision-making process, the following types of decisions were identified: (i) decision to internationalise; (ii) entry mode selection; (iii) foreign market selection; (iv) decision to change markets or entry modes; (v) strategic collaboration decisions; (vi) partner selection for collaboration; (vii) commitment decisions. The decision of a SME to start an internationalisation process is influenced by both internal (entrepreneurial orientation of the decision-maker and foreign language proficiency) and external factors (networks and relationships). A good knowledge base is crucial for making better internationalisation decisions and, as suggested by Casillas et al. (2010), SMEs need first to decide on how to seek information and learn from diverse sources (supra-organisational, organisational and individual) to start to internationalise. Entry mode 
selection and foreign market selection were identified as the most critical decisions for SMEs to internationalise. Although influenced by both internal and external factors, it seems that the decision of choosing the right entry mode is more dependent on the decision-maker capacity and the internal knowledge base possessed by a firm, while deciding on the foreign market to enter was mainly based on information and experiential knowledge from others (social and business relationships).

In addition, Francioni et al. (2013) were the only authors to analyse when do SMEs decide to change an entry mode or a foreign market, showing that these changes may occur not only due to social and business relationships, but also from proactive and reactive factors of decision-makers. In spite of their importance, there has been in fact little attention to these decisions, mainly because research is more focused on decisions in the first stages of the internationalisation process rather than the subsequent ones. This topic remains therefore open for additional research in the future.

The other three types of decisions (strategic collaboration decisions, partner selection for collaborations, and commitment decisions) were the ones less addressed in the articles of the SLR. It was clear the importance given to decisions about entry modes and market selection, and the factors that influence them. Although having a growing evidence in the literature on the importance of SMEs to establish collaborations with others to gain competitive advantage in internationalisation, there is a lack of comprehensive and systematic studies addressing how SMEs can access, organise and use the information generated in a collaborative network context, and how they can collaboratively convert this information into knowledge to support decision-making in internationalisation processes. This represents also one of the main suggestions for future research.

As previously stated, in addition to making collaborative strategic decisions, SMEs in collaborative networks need to select suitable partners for satisfying their needs of internationalisation (Spence et al., 2008). These partnerships can be done in a vertical way, with complementary companies or in a horizontal way with companies acting on their same competence area. According to Spence et al. (2008), an emerging trend is collaboration between SMEs and large firms to respond to the globalisation. Therefore, the development of collaborative decision-making models and approaches, based on a multiple criteria setting for relationship establishment, seems to make sense, and can represent another direction to be followed in future studies.

Lack of information and insufficient knowledge was identified as the main obstacles for firms to internationalise (Hsu et al., 2013; Sommer \& Haug, 2011). The lack of suitable tools, methods and practices for managing information and knowledge, both from previous experiences and from collaborations with other firms, is another hindrance in the internationalisation processes (Rodriguez et al., 2010). Internationalisation requires accessing, processing and organising large amounts of information (Xie \& Amine, 2009), so better information and knowledge management in collaboration, maybe through collaborative platforms, is likely to contribute substantially to improve the effectiveness of these processes. However, it is rather surprising the lack of exploratory studies on how state-of-the-art information management models and technologies can be used to significantly improve collaborative decision-making in the internationalisation of SMEs. Moreover, there is no evidence that networking and collaboration are systematically explored in the benefit of more effective internationalisation outcomes.

Important insights about the way information is accessed, processed and used by the decision-makers in internationalisation processes were analysed in this review: age, tenure, information processing capability, international experience and organisational memory are the ones to highlight. Again, this is a relevant topic posing interesting research challenges: do decision-makers have the right skills to cope with the increasing amount and diversity of information potentially useful to internationalisation decisions?

Additionally, general information subjects were identified, with the information about foreign markets conditions being recognised as the most relevant. Yet, there is no detailed systematic analysis on the specific content and subject of the information needed for making decisions in internationalisation. This, together with the previous point, set an important path for further research in information management for internationalisation processes. In fact, only a few pieces of research address explicitly the influence of information management in the internationalisation process of SMEs (Casillas et al., 2010; Child \& Hsieh, 2014; Dutot et al., 2014; Rodriguez et al., 2010; Santos-Alvarez \& García-Merino, 2010; Xie \& Amine, 2009). As previously shown, the topics addressed are limited to the identification of informational needs, general information subjects (e.g. attractiveness of host countries, internationalisation strategies, obstacles and support programmes), decision-makers' information capabilities, and considerations about information sharing. Therefore, there is a lot to explore regarding information organisation, information life-cycle, informational behaviour of the decision-makers, design of 
information models supporting internationalisation processes, and the design of IT platforms, necessarily collaborative, to support all the above.

In terms of knowledge management, it became clear that the knowledge assimilated by SMEs in internationalisation processes could be tacit and/or explicit in nature. In most of the situations, SMEs have more difficulties with tacit knowledge because it is subjective and hard to formalise (Camuffo et al., 2007; Fletcher \& Prashantham, 2011). Different types of knowledge are used, such as market knowledge, internationalisation knowledge, network knowledge, and technological knowledge. One can conclude that there is no specific rule about the use of certain types of knowledge. Instead, SMEs search and assimilate one or more types of knowledge from different sources, according to their specific needs and internationalisation strategies, entry modes or foreign markets to enter. For example, Akerman (2014) shows that the assimilation of market knowledge is essential for SMEs to obtain additional sales in foreign markets and to acquire new customers. In another direction, Mockaitis et al. (2006) found that most of the SMEs do not consider market knowledge as an important asset. Both studies analyse manufacturing firms, without focusing on "special" institutional contexts, such as start-ups, born global firms, or knowledge-intensive firms. The only difference is in the geographic context, i.e. the study of Akerman (2014) is on SMEs from a developed country, while Mockaitis et al. (2006) analyse SMEs from an emerging country. However, no specific conclusions can be drawn from these studies due to the lack of a more representative number of situations and data for supporting this finding. This is also an issue to be added to a possible research agenda, together with another suggestion by Akerman (2014) to study how the role of knowledge varies in the different stages of an internationalisation process.

In fact, the different contexts where SMEs are embedded have been pointed out by many researchers as an important aspect that needs to be studied. From the research directions of the literature, it seems to be a need to explore how different SMEs' contexts would result in different information and knowledge needs to internationalise. Kaur and Sandhu (2013) suggest that decisions (mainly concerning the entry mode selection) seem to be influenced by the nature and condition of the industrial sector in which the firm operates. In a later study, Dutot et al. (2014) also consider that the industry/sector type is an important context to analyse since SMEs operating in sectors with more uncertain environments might have larger information requirements than other SMEs operating with less amounts of uncertainty. According to Fletcher and Harris (2012) the sources of information and knowledge used by firms are clearly affected by their geographic context, this leading them to identify the need for research exploring how the geographic context would result in different knowledge needs, types and sources. These authors recognize that those sources are also significantly affected by the particular institutional contexts of firms. Finally, Child and Hsieh (2014) suggest that the decision mode to follow has implications for the information required and vice-versa. These different contexts, as described in the literature, were not addressed in this work, this representing an important direction for further research.

Another relevant theme that was not covered by this work is the broad list of different theories and conceptual frameworks that support the analysed articles: the Uppsala internationalisation model, the innovation-related internationalisation model, the network approach to internationalisation, theories of international entrepreneurship, the resource-based view, the knowledge-based view, the Dunning's eclectic paradigm, the upper echelons theory, the effectuation theory, the agency theory, the institutional theory, the theory of organisational learning, the theory of planned behaviour, and the Lindblom's muddling-through concept. Without getting into too much detail, it seems that, as suggested by Crick and Spence (2005), no single theory could fully explain decisions in internationalisation.

To close this discussion and research agenda section, one should mention the importance that governments and institutional supporting agencies, as well as some other public and private initiatives, may have in the internationalisation processes of SMEs. Several authors have recognised such importance (Table 7).

Table 7 - Importance of governments and institutional supporting agencies, and other public and private initiatives

\begin{tabular}{|l|l|}
\hline References & Findings and suggestions \\
\hline (Casillas et al., 2010) & $\begin{array}{l}\text { One company has frequently contacted public agencies for export activities to request } \\
\text { information on markets abroad. }\end{array}$ \\
\hline (Fletcher \& Prashantham, 2011) & $\begin{array}{l}\text { Firms acquire tacit knowledge from different externals sources, including consultants, } \\
\text { overseas government agencies and domestic support agencies. }\end{array}$ \\
\hline (Loane \& Bell, 2006) & $\begin{array}{l}\text { Support agencies, instead of only providing objective knowledge, should also shift } \\
\text { their focus to supporting experiential learning and network development of SMEs. } \\
\text { Firms should therefore recognise the importance of government support agencies as an } \\
\text { integral part of their knowledge development networks. }\end{array}$ \\
\hline
\end{tabular}




\begin{tabular}{|l|l|}
\hline (Child \& Hsieh, 2014) & $\begin{array}{l}\text { Advice and internationalisation programs of government support agencies should be } \\
\text { adapted to individual firm needs, through the improvement of their links to networks } \\
\text { and channels for other SMEs, in order to obtain the required assistance and to develop } \\
\text { key network relationships. }\end{array}$ \\
\hline (Crick \& Spence, 2005) & $\begin{array}{l}\text { The role of advisors and policy makers should not be overlooked due to the number of } \\
\text { private and public initiatives that have been developed to support SMEs in } \\
\text { internationalisation. Some examples are activities organised by trade associations to } \\
\text { facilitate contacts between domestic and foreign business executives, as well as } \\
\text { subsidised government programmes for SMEs that encourage the establishment of } \\
\text { networks, resulting in knowledge sharing and joint activities. }\end{array}$ \\
\hline (Hessels \& Terjesen, 2010) & $\begin{array}{l}\text { In order to help SMEs to internationalise, governments should develop efforts to: (i) } \\
\text { improve access to knowledge and technology; (ii) decrease production costs in the } \\
\text { home market; (iii) facilitate favourable investor access in the home market. }\end{array}$ \\
\hline (Kaur \& Sandhu, 2013) & $\begin{array}{l}\text { Existing assistance programmes are not capable to reach firms with efficiency or are } \\
\text { not useful enough for driving early internationalisation. Therefore, public policy } \\
\text { makers should work on the implementation of improved and more tailored public } \\
\text { support programmes, as well as on the promotion of the use of available support } \\
\text { programmes. }\end{array}$ \\
\hline
\end{tabular}

\section{Limitations}

This work has some natural limitations, and researchers in the area should be aware of those limitations when interpreting the material presented here. The SLR was based on journal articles of only two bibliographic databases: Web of Science and Scopus. Although covering a wide range of articles and journals in different areas, some other databases (e.g. EBSCO) may also present valuable research articles that could have been missed in this review. In fact, some other relevant articles from the analysed bibliographic databases may have been excluded due to the subjective first analysis, or even due to the choice of search strings. The review is only focused on SMEs but some findings obtained by studies focusing on MNEs may also be relevant in the context of SMEs.

Different internationalisation theories, conceptual frameworks and other specific theories support the analysed works. However, a detailed analysis to know those that better explain internationalisation behaviours and decisions was not performed. In addition, a thorough analysis about the different contexts (geographic, institutional, industry/sector) that may impact information and knowledge management needs of SMEs was not accomplished. The CIMO-logic described in Denyer, Tranfield, and van Aken (2008) can be a useful tool to describe the different contexts-interventions-mechanisms-outcomes of the areas considered in this paper. This might be an interesting topic for future research. However, one should note that this paper has already made a first contribution in this direction, presenting results for interventions (I) and outcomes (O) of the CIMO-logic, and that there is a need for exploring the contexts (C) and mechanisms (M). Therefore, this literature review may not be very comprehensive but it provides new insights complementing knowledge generated by previous studies, and it may help to stimulate further relevant research.

\section{Conclusion}

Based on empirical findings from previous studies, the objective of this work was to analyse, synthesise and present a comprehensive SLR on the role of information, knowledge and collaboration in decision-making for internationalisation processes of SMEs. The SLR methodology proved to be a useful tool for moving away from descriptive reviews of the literature, with contributions including the synthesis of main findings of the literature, the identification of gaps, and the establishment of a basis for future research.

One can hope that the results of this study will assist both academics and professionals to develop new tools and methodologies, based on state-of-the-art technologies. Additionally the development of collaborative decisionmaking models and approaches seems to be an important requirement of SMEs to manage collaboration in international strategies, mainly for partner selection. Governments and institutional supporting agencies are likely to play an interesting role in practically supporting international strategies of SMEs, mainly through experiential learning and network development. 


\section{Acknowledgements}

This research was partially funded by the North Portugal Regional Operational Programme (ON.2-O Novo Norte), under the National Strategic Reference Framework (NSRF), through the European Regional Development Fund (ERDF), and by national funds, through the Portuguese funding agency, Fundação para a Ciência e a Tecnologia (FCT), within the project NORTE-07-0124-FEDER-000057. The first author was also funded by the Ph.D. Studentship SFRH/BD/110131/2015 from FCT.

\section{References}

Adner, R., \& Levinthal, D. A. (2004). What is not a real option: Considering boundaries for the application of real options to business strategy. Academy of Management Review, 29(1), 74-85. doi:10.5465/AMR.2004.11851715

Akerman, N. (2014). An international learning typology: Strategies and outcomes for internationalizing firms. Baltic Journal of Management, 9(4), 382-402. doi:10.1108/bjm-12-2013-0176

Andersson, S. (2011). International entrepreneurship, born globals and the theory of effectuation. Journal of Small Business and Enterprise Development, 18(3), 627-643. doi:10.1108/14626001111155745

Aspelund, A., \& Butsko, V. (2010). Small and middle-sized enterprises' offshoring production: A study of firm decisions and consequences. Tijdschrift Voor Economische En Sociale Geografie, 101(3), $262-275$. doi:10.1111/j.1467-9663.2009.00585.x

Barney, J. (1991). Firm resources and sustained competitive advantage. Journal of Management, 17(1), 99-120. doi: $10.1177 / 014920639101700108$

Basly, S. (2007). The internationalization of family SME: An organizational learning and knowledge development perspective. Baltic Journal of Management, 2(2), 154-180. doi:10.1108/17465260710750973

Benito, G., Solberg, C., \& Welch, L. (1993). An exploration of the information behaviour of Norwegian exporters. International Journal of Information Management, 13(4), 274-286. doi:10.1016/0268-4012(93)90018-Y

Camargo-Pérez, J., Carrillo, M., \& Montoya-Torres, J. (2014). Multi-criteria approaches for urban passenger transport systems: A literature review. Annals of Operations Research, 226(1), 69-87. doi:10.1007/s10479014-1681-8

Camarinha-Matos, L., \& Afsarmanesh, H. (2005). Collaborative networks: A new scientific discipline. Journal of Intelligent Manufacturing, 16(4-5), 439-452. doi:10.1007/s10845-005-1656-3

Camuffo, A., Furlan, A., Romano, P., \& Vinelli, A. (2007). Routes towards supplier and production network internationalisation. International Journal of Operations \& Production Management, 27(4), 371-387. doi:10.1108/01443570710736967

Cannone, G., \& Ughetto, E. (2014). Born globals: A cross-country survey on high-tech start-ups. International Business Review, 23(1), 272-283. doi:10.1016/j.ibusrev.2013.05.003

Casillas, J., Acedo, F., \& Barbero, J. (2010). Learning, unlearning and internationalisation: Evidence from the preexport phase. International Journal of Information Management, 30(2), $162-173$. doi:10.1016/j.ijinfomgt.2009.07.005

Castellacci, F. (2014). Service firms heterogeneity, international collaborations and export participation. Journal of Industry, Competition and Trade, 14(2), 259-285. doi:10.1007/s10842-013-0153-1

Chen, H.-L. (2011). Does board independence influence the top management team? Evidence from strategic decisions toward internationalization. Corporate Governance: An International Review, 19(4), 334-350. doi:10.1111/j.1467-8683.2011.00850.x

Child, J., Duarte, R., Tanure, B., \& Rodrigues, S. (2012). Access to tacit knowledge by executive retention in cross-border acquisitions. BAR - Brazilian Administration Review, 9(3), 329-350. doi:10.1590/s180776922012000300006

Child, J., \& Hsieh, L. (2014). Decision mode, information and network attachment in the internationalization of SMEs: A configurational and contingency analysis. Journal of World Business, 49(4), 598-610. doi:10.1016/j.jwb.2013.12.012

Ciravegna, L., Lopez, L., \& Kundu, S. (2014). Country of origin and network effects on internationalization: A comparative study of SMEs from an emerging and developed economy. Journal of Business Research, 67(5), 916-923. doi:10.1016/j.jbusres.2013.07.011

Colicchia, C., \& Strozzi, F. (2012). Supply chain risk management: A new methodology for a systematic literature review. Supply Chain Management: An International Journal, 17(4), 403-418. 
doi: $10.1108 / 13598541211246558$

Coviello, N., \& Munro, H. (1997). Network relationships and the internationalisation process of small software firms. International Business Review, 6(4), 361-386. doi:10.1016/S0969-5931(97)00010-3

Covin, J. (1991). Entrepreneurial versus conservative firms: A comparison of strategies and performance. Journal of Management Studies, 28(5), 439-462. doi:10.1111/j.1467-6486.1991.tb00763.x

Crick, D., \& Spence, M. (2005). The internationalisation of "high performing" UK high-tech SMEs: A study of planned and unplanned strategies. International Business Review, 14(2), 167-185. doi:10.1016/j.ibusrev.2004.04.007

Cui, L., Li, Y., \& Li, Z. (2013). Experiential drivers of foreign direct investment by late-comer Asian firms: The Chinese evidence. Journal of Business Research, 66(12), 2451-2459. doi:10.1016/j.jbusres.2013.05.034

Denyer, D., \& Tranfield, D. (2009). Producing a systematic review. In The Sage Handbook of Organizational Research Methods (pp. 671-689).

Denyer, D., Tranfield, D., \& van Aken, J. (2008). Developing design propositions through research synthesis. Organization Studies, 29(3), 393-413. doi:10.1177/0170840607088020

Dretske, F. (1981). Knowledge and the flow of information. Cambridge, MA: MIT Press.

Dunning, J. (1988). The eclectic paradigm of international production: A restatement and some possible extensions. Journal of International Business Studies, 19(1), 1-31. doi:10.1057/palgrave.jibs.8490372

Dutot, V., Bergeron, F., \& Raymond, L. (2014). Information management for the internationalization of SMEs: An exploratory study based on a strategic alignment perspective. International Journal of Information Management, 34(5), 672-681. doi:10.1016/j.ijinfomgt.2014.06.006

Fletcher, M., \& Harris, S. (2012). Knowledge acquisition for the internationalization of the smaller firm: Content and sources. International Business Review, 21(4), 631-647. doi:10.1016/j.ibusrev.2011.07.008

Fletcher, M., \& Prashantham, S. (2011). Knowledge assimilation processes of rapidly internationalising firms: Longitudinal case studies of Scottish SMEs. Journal of Small Business and Enterprise Development, 18(3), 475-501. doi:10.1108/14626001111155673

Francioni, B., Musso, F., \& Vardiabasis, D. (2013). Key decisions and changes in internationalization strategies: The case of smaller firms. Journal of Strategic Marketing, 21(3), $240-259$. doi:10.1080/0965254X.2013.790466

Grant, R. (1991). The resource-based theory of competitive advantage: Implications for strategy formulation. California Management Review, 33(3), 114-135. doi:10.1016/S0149-2063(99)00037-9

Grant, R. (1996). Toward a knowledge-based theory of the firm. Strategic Management Journal, 17(S2), 109-122. doi: $10.1002 / \mathrm{smj} .4250171110$

Hambrick, D., \& Mason, P. (1984). Upper echelons: The organization as a reflection of its top managers. The Academy of Management Review, 9(2), 193-206. doi:10.2307/258434

Hassini, E., Surti, C., \& Searcy, C. (2012). A literature review and a case study of sustainable supply chains with a focus on metrics. International Journal of Production Economics, 140(1), 69-82. doi:10.1016/j.ijpe.2012.01.042

Hessels, J., \& Terjesen, S. (2010). Resource dependency and institutional theory perspectives on direct and indirect export choices. Small Business Economics, 34(2), 203-220. doi:10.1007/s11187-008-9156-4

Hsu, W.-T., Chen, H.-L., \& Cheng, C.-Y. (2013). Internationalization and firm performance of SMEs: The moderating effects of CEO attributes. Journal of World Business, 48(1), 1-12. doi:10.1016/j.jwb.2012.06.001

Hultman, J., Johnsen, T., Johnsen, R., \& Hertz, S. (2012). An interaction approach to global sourcing: A case study of IKEA. Journal of Purchasing and Supply Management, 18(1), 9-21. doi:10.1016/j.pursup.2011.11.001

Hutchinson, K., Alexander, N., Quinn, B., \& Doherty, A. (2007). Internationalization motives and facilitating factors: Qualitative evidence from smaller specialist retailers. Journal of International Marketing, 15(3), 96-122. doi:10.1509/jimk.15.3.96

Ibeh, K., \& Kasem, L. (2011). The network perspective and the internationalization of small and medium sized software firms from Syria. Industrial Marketing Management, 40(3), 358-367. doi:10.1016/j.indmarman.2010.08.004

Johanson, J., \& Vahlne, J.-E. (1977). The internationalization process of the firm: A model of knowledge development and increasing foreign market commitments. Journal of International Business Studies, 8(1), 23-32. doi:10.1057/palgrave.jibs.8490676

Kalinic, I., Sarasvathy, S., \& Forza, C. (2013). "Expect the unexpected": Implications of effectual logic on the internationalization process. International Business Review, 23(3), 635-647. doi:10.1016/j.ibusrev.2013.11.004 
Kamal, M., \& Irani, Z. (2014). Analysing supply chain integration through a systematic literature review: A normative perspective. Supply Chain Management: An International Journal, 19(5/6), 523-557. doi:10.1108/SCM-12-2013-0491

Kaur, S., \& Sandhu, M. (2013). Internationalisation of born global firms: Evidence from Malaysia. Journal of the Asia Pacific Economy, 19(1), 101-136. doi:10.1080/13547860.2013.818426

Knight, G. A., \& Liesch, P. W. (2002). Information internalisation in internationalising the firm. Journal of Business Research, 55(12), 981-995. doi:10.1016/S0148-2963(02)00375-2

Kollmann, T., \& Christofor, J. (2014). International entrepreneurship in the network economy: Internationalization propensity and the role of entrepreneurial orientation. Journal of International Entrepreneurship, 12(1), 4366. doi:10.1007/s10843-013-0118-9

Lindblom, C. (1959). The science of "muddling through." Public Administration Review, 19(2), 79-88. doi: $10.2307 / 973677$

Loane, S., \& Bell, J. (2006). Rapid internationalisation among entrepreneurial firms in Australia, Canada, Ireland and New Zealand: An extension to the network approach. International Marketing Review, 23(5), 467-485. doi:10.1108/02651330610703409

London, K. (2010). Multi-market industrial organizational economic models for the internationalization process by small and medium enterprise construction design service firms. Architectural Engineering and Design Management, 6(2), 132-152. doi:10.3763/aedm.2009.0111

Malik, T. (2012). First mover, strategic alliances and performance: Context of turmoil in China. Chinese Management Studies, 6(4), 647-667. doi:10.1108/17506141211280308

McDougall, P., \& Oviatt, B. (2000). International entrepreneurship: The intersection of two research paths. The Academy of Management Journal, 43(5), 902-906. doi:10.2307/1556418

Mejri, K., \& Umemoto, K. (2010). Small- and medium-sized enterprise internationalization: Towards the knowledge-based model. Journal of International Entrepreneurship, 8(2), 156-167. doi:10.1007/s10843010-0058-6

Mockaitis, A., Vaiginienè, E., \& Giedraitis, V. (2006). The internationalization efforts of lithuanian manufacturing firms-strategy or luck? Research in International Business and Finance, 20(1), 111-126. doi:10.1016/j.ribaf.2005.02.001

Musteen, M., Francis, J., \& Datta, D. (2010). The influence of international networks on internationalization speed and performance: A study of Czech SMEs. Journal of World Business, 45(3), 197-205. doi:10.1016/j.jwb.2009.12.003

Nguyen, T., Barrett, N., \& Fletcher, R. (2006). Information internalisation and internationalisation: Evidence from Vietnamese firms. International Business Review, 15(6), 682-701. doi:10.1016/j.ibusrev.2006.09.001

Nonaka, I. (1994). A dynamic theory of organizational knowledge creation. Organization Science, 5(1), 14-37. doi:10.1287/orsc.5.1.14

Nonaka, I., \& Takeuchi, H. (1995). The knowledge-creating company: How Japanese companies create the dynamics of innovation. New York: Oxford University Press.

Ojala, A. (2009). Internationalization of knowledge-intensive SMEs: The role of network relationships in the entry to a psychically distant market. International Business Review, 18(1), 50-59. doi:10.1016/j.ibusrev.2008.10.002

Ojala, A., \& Tyrväinen, P. (2008). Market entry decisions of US small and medium-sized software firms. Management Decision, 46(2), 187-200. doi:10.1108/00251740810854113

Peng, Y.-S., Yang, K.-P., \& Liang, C.-C. (2011). The learning effect on business groups' subsequent foreign entry decisions into transitional economies. Asia Pacific Management Review, 16(1), 1-21.

Pinho, J. (2007). The impact of ownership: Location-specific advantages and managerial characteristics on SME foreign entry mode choices. International Marketing Review, 24(6), 715-734. doi:10.1108/02651330710832676

Rodriguez, V., Barcos, L., \& Álvarez, J. (2010). Managing risk and knowledge in the internationalisation process. Intangible Capital, 6(2), 202-235. doi:10.3926/ic.2010.v6n2.202-235

Root, F. R. (1994). Entry strategies for international markets. New York: Lexington Books.

Santos-Alvarez, V., \& García-Merino, T. (2010). The role of the entrepreneur in identifying international expansion as a strategic opportunity. International Journal of Information Management, 30(6), 512-520. doi:10.1016/j.ijinfomgt.2010.03.008

Schweizer, R. (2012). The internationalization process of SMEs: A muddling-through process. Journal of Business Research, 65(6), 745-751. doi:10.1016/j.jbusres.2010.12.011

Sedoglavich, V. (2012). Technological imperatives in the internationalization process: Results from a qualitative 
investigation of high-tech SMEs. Management Research Review, 35(5), 441-459. doi:10.1108/01409171211222386

Simon, H. (1955). A behavioral model of rational choice. The Quarterly Journal of Economics, 69(1), 99-118. doi: $10.2307 / 1884852$

Sommer, L., \& Haug, M. (2011). Intention as a cognitive antecedent to international entrepreneurship: Understanding the moderating roles of knowledge and experience. International Entrepreneurship and Management Journal, 7(1), 111-142. doi:10.1007/s11365-010-0162-z

Spence, M., Manning, L., \& Crick, D. (2008). An investigation into the use of collaborative ventures in the internationalization of high performing Canadian SMEs. European Management Journal, 26(6), 412-428. doi:10.1016/j.emj.2008.09.006

Torkkeli, L., Puumalainen, K., Saarenketo, S., \& Kuivalainen, O. (2012). The effect of network competence and environmental hostility on the internationalization of SMEs. Journal of International Entrepreneurship, 10(1), 25-49. doi:10.1007/s10843-011-0083-0

Townsend, J. (2003). Understanding alliances: A review of international aspects in strategic marketing. Marketing Intelligence \& Planning, 21(3), 143-155. doi:10.1108/02634500310474966

Tranfield, D., Denyer, D., \& Smart, P. (2003). Towards a methodology for developing evidence-informed management knowledge by means of systematic review. British Journal of Management, 14(3), $207-222$. doi:10.1111/1467-8551.00375

Wong, C., Skipworth, H., Godsell, J., \& Achimugu, N. (2012). Towards a theory of supply chain alignment enablers: A systematic literature review. Supply Chain Management: An International Journal, 17(4), 419437. doi:10.1108/13598541211246567

Xie, Y., \& Amine, L. (2009). Social networks and the internationalization of Chinese entrepreneurs. Global Business and Organizational Excellence, 29(1), 61-78. doi:10.1002/joe.20299

Zhou, L., Wu, W., \& Luo, X. (2007). Internationalization and the performance of born-global SMEs: The mediating role of social networks. Journal of International Business Studies, 38(4), 673-690. doi:10.1057/palgrave.jibs.8400282

Židonis, Ž. (2007). Entrepreneurial internationalisation: A case study of Libra company. Baltic Journal of Management, 2(3), 273-287. doi:10.1108/17465260710817483

Zucchella, A., \& Servais, P. (2012). The internationalisation process of small- and medium-sized firms and the liability of complexity. International Journal of Entrepreneurship and Small Business, 15(2), 191-212. doi:10.1504/IJESB.2012.045204 